of ultimate agreement is surely the hallmark of all scientific activity.

Nevertheless, the strong emphasis here laid on the individual provides $\mathrm{a}$ corrective to much contemporary thinking. In an inspiring address on "The Struggle for Intellectual Integrity" the commonly held belief that science is ethically neutral is implicitly controverted in a carefully argued claim that "the activity which par excellence demands and exemplifies intellectual honesty is the scientific". We are also given a timely reminder that the mainspring of scientific activity is the craving for understanding. Indeed, Bridgman would agree that its object, as Jacobi pointed out in a famous retort to Fourier, is "the honour of the human mind".

Despite an occasional jarring split infinitive, the style of most of these talks and addresses is admirable, and it is difficult to put the book down when once begun. This is a work of immediate importance and at the same time of permanent significance, of value both to the 'external' and the 'internal' study of science.

The printing is excellent, the binding ugly. G. J. WHITROW

\section{PREHISTORY IN NORTHERN RHODESIA}

The Stone Age Cultures of Northern Rhodesia With Particular Reference to the Cultural and Climatic Succession in the Upper Zambezi Valley and its Tributaries. By J. Desmond Clark; with a Chapter on the Geology, by Dr. F. Dixey, and Appendixes by H. B. S. Cooke, L. H. Wells and Geoffrey Bond. Pp. xii + 157. (Claremont, Cape: South African Archæological Society, 1950.) 21s.

$\mathrm{D}$ R. DESMOND CLARK is the curator of the Rhodes-Livingstone Museum. He received his archæological training at Cambridge in the Faculty of Archæology and Anthropology, and has since had the opportunity of travelling widely in Africa during and since the Second World War. This present work is the major part of a thesis submitted for a Ph.D. degree, and its publication in book form has been undertaken by the South African Archæological Society. There is included a chapter on the geology by Dr. F. Dixey, and appendixes by H. B. S. Cooke, L. H. Wells and Geoffrey Bond on Quaternary fossils from Northern Rhodesia, on fossil man in the area, and on the dating of deposits of Kalahari sand, respectively. There are a number of plates, figures and diagrams illustrating the general features of the country, the industries found, and various sections and maps. The whole is a first-class piece of work, dealing with a crucial region from the point of view of the prehistory of South Africa, and indispensable for every student of early man in that part of the world.

Dr. Dixey opens with a general account of the geology of the Zambezi Valley. It is based not on the evidence of vague mapping, but on a detailed survey of the region. Interesting is the fact that the earliest (pebble) industries seem to appear in the region slightly later than they do in East Africa. This tends to confirm the idea-also applied to the rather later Stone Age cultures-that there were continual migrations into the sub-continent from elsewhere which had to pass over the barrier of the Zambezi, and that the size of the river and the diffi- culties of crossing it created a bottle-neck or -necks through which the migrating folk had to pass before they could fan out over the easier country of Southern Rhodesia and the Union.

Clark carries on in Part 2 with an account of the stratigraphy and cultural succession, followed by a description of the industries associated with the various cultures. A series of invaluable sections is given which relates the various finds of archæological material with the geological succession already determined. A climate sequence for the several cultures can thence be determined, and it is interesting to see how this agrees with similar climate sequences in other parts of Africa. The cultures found include, of course, an early pebble-tool making culture, the Chelleo-Acheulean culture, the Sangoan, Still Boy, Magosian, Wilton and Neolithic. In the Nachikufu Caves there are some paintings, of no great beauty, but interesting from the locality where they occur.

The volume concludes with the various appendixes. The whole is a sound and solid piece of work ; doubtless there will be further details to add, but the foundations for the study of Northern Rhodesian prehistory have been well and truly laid.

M. C. BurkItT

\section{ORGANIC CHEMISTRY FOR HONOURS STUDENTS}

Perkin and Kipping's Organic Chemistry By Prof. F. Stanley Kipping and F. Barry Kipping. Now edition. Part 1. Pp. xi $370+$ xxxii. 7s. $6 d$. Part 2. Pp. $x i+371-694+$ xxxii. 7s. 6d. Part 3. Pp. xii +695-1130+xxxiii-Iviii. 12s. 6d. (Edinburgh and London: W. and R. Chambers, Ltd., 1949.)

THIS new edition of "Perkin and Kipping", written by the late Prof. F. S. Kipping and by Dr. F. B. Kipping, will be accorded by students the same welcome to-day as was the original "Perkin and Kipping" by their grandfathers. The handy three-volume pocket size and reasonable price will appeal to students. This edition has clearly been substantially rewritten and entirely reset. The number of pages has been increased, but this is due to the use of a larger and more pleasing type-face as well as to the incorporation of additional material. The reader is quickly struck by the clarity of the formulæ of cyclic compounds, particularly those of heterocyclic compounds, in which five- and sixmembered ring systems are drawn as regular pentagons and hexagons respectively. The authors, artist and block-maker are to be congratulated on this welcome innovation.

Parts 1 and 2 constitute an introduction to organic chemistry. The subject is treated from a practical point of view, preparative details being interspersed in the text, and the preparations and reactions of individual compounds are elaborated before generalizations, in the form of chapter summaries, are made. Simple theoretical ideas, such as those of resonance, are integrated throughout the text instead of being relegated to a chapter at the end. Heterocyclic compounds are given more extensive treatment than is usual in a text-book of an introductory character. Following this introduction, the subsequent use of Part 3 will go a good way to satisfying the requirements of honours students. The descriptive chapters 